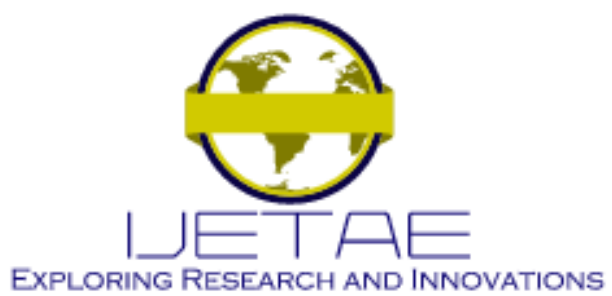

International Journal of Emerging Technology and Advanced Engineering

Website: www.ijetae.com (E-ISSN 2250-2459, Scopus Indexed, ISO 9001:2008 Certified Journal, Volume 11, Issue 12, December 2021)

Manuscript Received: 02 November 2021, Received in Revised form: 02 December 2021, Accepted: 08 December 2021

DOI: 10.46338/ijetae1221_02

\title{
Design of a Distance Detection System for Patients in a Health Center
}

\author{
Rosa Perez-Siguas ${ }^{1}$, Eduardo Matta-Solis ${ }^{2}$, Hernan Matta-Solis ${ }^{3}$ \\ ${ }^{1,2,3}$ Universidad María Auxiliadora \& Av. Canto Bello 431, San Juan de Lurigancho
}

\begin{abstract}
COVID-19 was declared by the World Health Organization (WHO) as a pandemic on March $11^{\text {th }}, 2020$, because it is a highly contagious viral infection. It infected more than 153 million people until the beginning of May 2021 and caused more than 3.2 million deaths worldwide. In Peru, the first case was reported on March $6^{\text {th }}, 2020$, days later the entire country was quarantined to prevent the spread of COVID-19 and not further complicate the health system. With this, it affected economically many people who did not have a full-time job; therefore, the government reactivated some activities if they comply with biosafety measures, among them is social distancing, being important to keep it at least two meters from other people whenever possible, but unfortunately people fail to comply with this measure. In view of this problem, this article will carry out the design of a distance detection system for patients in a health center, in such a way that the system performs the most exact measurement of the distance between people, and it can be implemented in any place where there is an agglomeration of people to put order within the place. Through, the design of the system, will work in the most appropriate way, in such a way that it will help to prevent the spread of COVID-19 that currently continues to affect many countries.
\end{abstract}

Keywords-- Surveillance camera, Centroids, COVID-19, Python, WHO, Peru, Image processing.

\section{INTRODUCCIÓN}

COVID-19 was declared a pandemic by the World Health Organization (WHO) on March $11^{\text {th }}, 2020$ [1] because it is a highly contagious viral infection. It infected more than 153 million people until the beginning of May 2021 and caused more than 3.2 million deaths worldwide [2]; It originated in the city of Wuhan (China) on December $31^{\text {st }}, 2019$ [3] and remains to this day the largest event in contemporary history that has put the whole of humanity in serious difficulty due to the ravages so much in health systems and in the productive, commercial and financial chains of the world economy [4].

In Peru, the first case was reported on March $6^{\text {th }}, 2020$ [5], after a few days the government decides to declare a state of national emergency, quarantining the entire country.
Suspending all kinds of social activity that generates an agglomeration of people, to avoid continuing to spread the virus and further complicate the health system. According to Dr. Ciro Maguiña Vargas, he mentioned that this new disease (COVID-19) has uncovered in a crude and real way the terrible health situation in Peru [6]. Likewise, from the arrival in the country of COVID-19 until January 30, 2021, 474,199 cases of COVID-19 and 16,237 deaths were confirmed nationwide [7], without making any age distinction because it affected young people, adults and the elderly.

However, the COVID-19 pandemic affected the education sector throughout 2020 [8], due to the suspension of face-to-face classes in all educational institutions nationwide. It also brought with it a negative impact on the economy of millions of Peruvians [9], many lost their jobs, on the other hand, there were also people who depended on the day to day to survive; As the number of infections decreased, the government decided to resume some activities, but complying with biosafety measures, the same that must be applied by all organizations that restart work activities [10], which are mainly social distancing and use mandatory mask.

Social distancing is one of the prevention measures to avoid the spread of COVID-19, but people violate the rules, especially in health centers where places are closed and there is a lot of ventilation. Therefore, infections continue to increase [11]. It is important to maintain a distance of at least two meters from other people whenever possible [12], this could prevent the spread of COVID-19 that currently continues to affect many people. In addition to helping people who are at higher risk of contracting it.

The objective of this research work is to design a distance detection system for patients within a health center to enforce the corresponding distance between people who are within a health center, with this, the spread of the virus between the people who are queuing either to make a query or a procedure. 


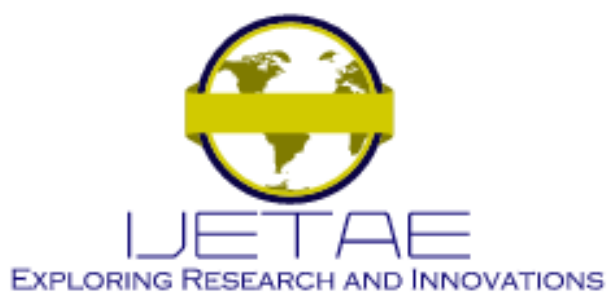

International Journal of Emerging Technology and Advanced Engineering Website: www.ijetae.com (E-ISSN 2250-2459, Scopus Indexed, ISO 9001:2008 Certified Journal, Volume 11, Issue 12, December 2021)

For the elaboration of the system, the information from the videos of the people with a static background will be analyzed, at a height of three meters, in addition to the location of centroids by the moment method and distance estimation by the Euclidean method, this, using language Python programming. Python is a very friendly programming language that can be understood by any reader with basic programming knowledge.

In section II, a review was made of some research previously developed. In section III, the methodology will indicate the diagram about the functionality of the system. In section IV, the detection of persons for theft of the substance will be indicated. In section $\mathrm{V}$, the estimate of the distance between people will be indicated. In section VI, the results that are generated according to the tests conducted with the system design will be presented. In section VII, the discussion will be presented, where the importance of this work with respect to other work conducted will be indicated. Finally, in section VIII, the conclusion and recommendation obtained from the design of the system will be presented.

\section{LITERATURE REVIEW}

It is not possible to know briefly if a person has COVID19 , for this it is necessary to conduct a test or medical study. Therefore, it is necessary to maintain the corresponding distance with other people, for this you can use a system that, through captured images, can detect if social distancing is fulfilled. For example: In [13], the authors identified that COVID-19 being a highly infectious virus, by means of an effective non-pharmaceutical measure to stop the spread of COVID-19 is social distancing and that it can be controlled by an air vehicle unmanned (UAV) as it is a flexible mobile platform, that is why they proposed a system for the precise and real-time detection of pedestrians with unmanned aerial vehicles for the supervision of social distancing in the COVID-19 pandemic. The proposed method consists of a specific light pedestrian detection network for head detection, which follows the PeleeNet as the backbone and incorporates multiscale characteristics and spatial attention. Obtaining as an experimental result of the Merge-Head data set an efficiency of $92.22 \%$ AP (medium precision) and 76 FPS (frames per second), concluding that the object detection method applied in this paper was highly effective.
In [14], the authors identified that people do not respect social distancing, therefore it has to be supervised by the government because COVID-19 spreads through people, especially in densely populated areas, for that is why the government needs a crowd surveillance system that can detect the presence of people, identify the crowd and give notices of social distancing, that is why they proposed to design the COVID-19 social distancing surveillance system in an effective, efficient way and safe, thus using road segmentation in the IRIS PX4 drone in the Robots Operating System and the Gazebo simulation that together with the algorithm to detect people or objects YOLO-v3, define a social distancing detector. Obtaining as a result an efficiency of detection of people and crowds located around $90.1 \%$, concluding that drones can also be equipped with thermal sensors so that the COVID-19 inspection can be identified.

In [15], the authors identified that in shopping centers the distance between the employee and the client is not fulfilled at the time of taking the temperature and disinfection of hands, that is why they proposed to develop a web system to monitor body temperature with automatic antibacterial gel dispenser to prevent COVID-19 infections in commercial premises of Guayaquil. The proposed method consists of using an Arduino mega board to automate the temperature measurement and hand disinfection system, also, with the PHP programming language a web system is developed to monitor the temperatures taken, in the MYSQL database thus leading greater control of cases. Obtaining as a result an efficiency of $98.1 \%$, the body temperature measurement system will provide antibacterial gel for those with a normal temperature (less than or equal to $37.5^{\circ}$ ) and restrict access to those with a high temperature (greater than $37.5^{\circ}$ ), concluding that the project is optimal in terms of time and costs, this is due to the technological tools used that are open source, thus allowing them to be used freely and easily.

Finally, in [16], the author identified that since there is no effective solution for COVID-19, one has to follow the recommendations of the authorities and health organizations, which are the use of masks, maintain two meters of social distance, wash hands frequently, avoid frequent contact with the mouth or nose. 


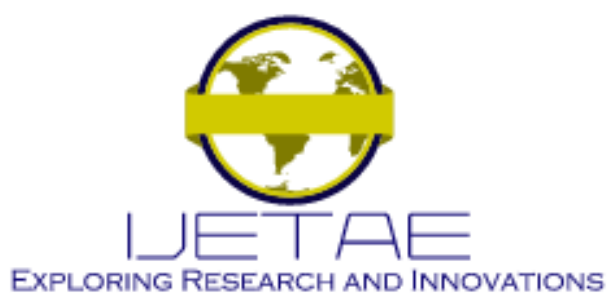

International Journal of Emerging Technology and Advanced Engineering Website: www.ijetae.com (E-ISSN 2250-2459, Scopus Indexed, ISO 9001:2008 Certified Journal, Volume 11, Issue 12, December 2021)

Of all these measures, social distancing is something that cannot be controlled, which is why it was proposed to implement a social distancing recognition system as a preventive measure for COVID-19 using Deep Learning. The proposed method consists of using the YOLO version 3 object detection model trained with the COCO image set, obtaining as a result an accuracy of $80 \%$, concluding that the system correctly detects social distancing and that it was also highly effective in detection. of people with high scores at each detection.

\section{METHODOLOGY}

In this part, the functionality diagram of the distance detection system in health centers will be made, as shown in

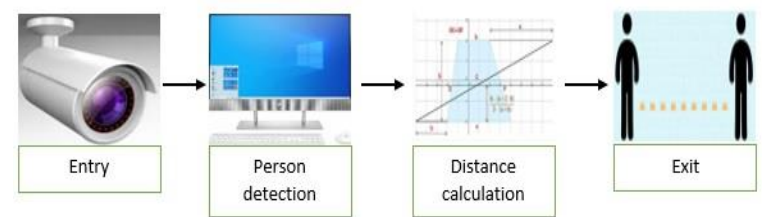

figure 1 . With this system the distance between people will be measured.

Fig. 1. System functionality diagram

Next, the stages that are part of the people detection system will be described.

\section{A. Entry stage}

In the entry stage, it is the part where the images obtained from the surveillance cameras located in the place are entered into the system. It should be noted that the cameras must be at a height of three meters from the ground, this is important because you want to have larger images so that the system can analyze the people who are in the place.

It is also important that the surveillance cameras have a line of sight, that is, that there are no obstacles that prevent the corresponding images from being obtained.

\section{B. Person detection stage}

In the people detection stage, it is the part where the background subtraction technique and the Otsu method are used. These techniques are used because they allow us to obtain better threshold values in the face of the variation in pixel brightness that may exist in the images obtained from the surveillance camera.

By using this technique, the person in circulation can be separated from the background of the image. With this, the people who are in the place could already be detected.

\section{Distance calculation stage}

In the distance calculation stage, it is the mathematical part, where once people are detected, the location of centroids must be used to know where they are.

Once the location point is located, the Euclidean method is used to know the distance between them. And so, the system would calculate the distance of the points in which the people are located.

\section{Exit stage}

In the exit stage, it is the part where the system already performed all the calculation so that it shows the numerical value of the distance in which the people are. With this numerical value, you can already know if the person complies with the important biosecurity measure that helps prevent the spread of COVID-19.

\section{Detection Of PEOPLE}

To detect people, image processing must be performed. To do this, you must go to grayscale, once converted, the background subtraction is performed; With the help of the Otsu method, the similarity between the object and the background is changed.

\section{A. Grayscale}

A grayscale image or RGB2GRAY, converts an RGB image to grayscale, that is, it changes the intensity of each color in values of 0 (black) and 1 (white). To be able to analyze a grayscale image in the Python program, you need to use some commands, as shown below:

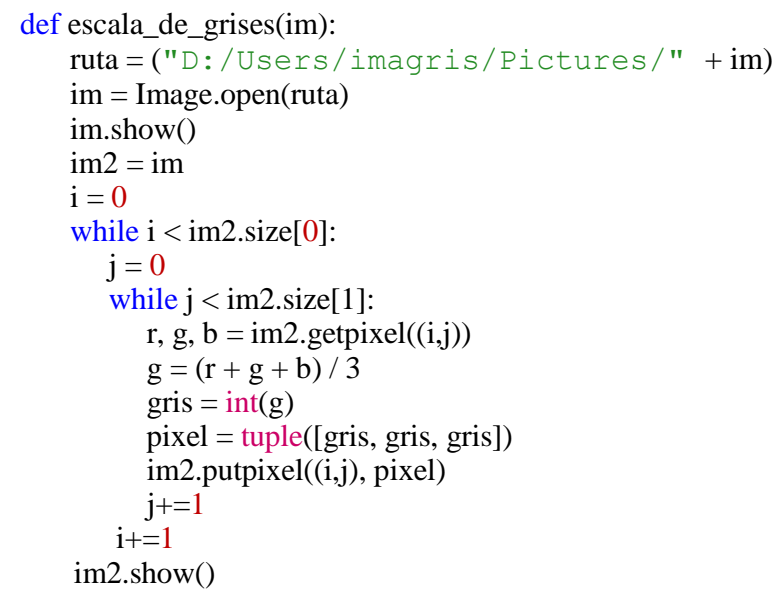

An example of a grayscale image is shown in Figure 2. 


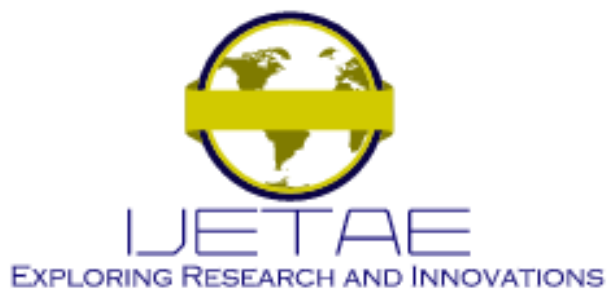

International Journal of Emerging Technology and Advanced Engineering

Website: www.ijetae.com (E-ISSN 2250-2459, Scopus Indexed, ISO 9001:2008 Certified Journal, Volume 11, Issue 12, December 2021)

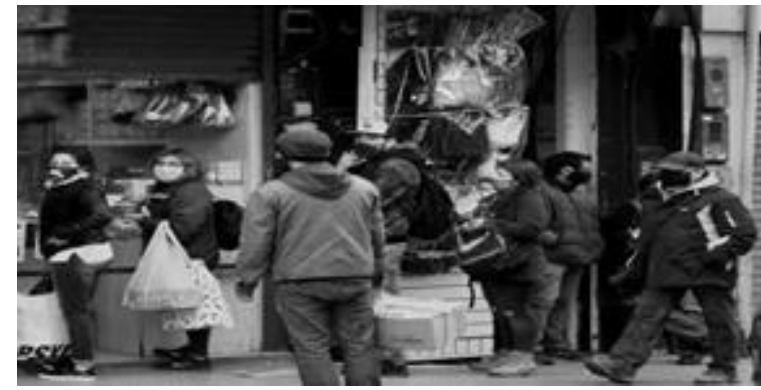

Fig. 2. Grayscale image

\section{B. Subtraction of the background}

Background subtraction is a technique that detects changes in the position of objects in a video image. In general terms, the technique consists of making a subtraction between the frame of the image that

will be processed and the background of it, thus obtaining the object present in the video frame [17].

To analyze an image with background subtraction in the Python program, it is necessary to use some commands, to reach figure 3 . There you can see an image to which the background subtraction technique was applied.

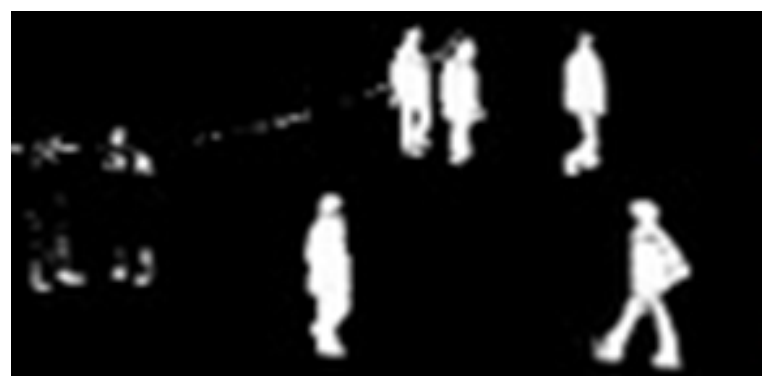

Fig. 3. Image with background subtraction

\section{Otsu Method}

The Otsu method is used when there is a clear difference between the objects to be extracted from the background of the scene.

In this method, the optimal threshold is chosen by maximizing the variance between classes using an exhaustive search. As the number of classes in an image increase, the Otsu method takes much longer to select a suitable multilevel threshold.

Thresholding creates binary images from gray-level images to set all pixels below a threshold to zero and all pixels above that threshold to one [18]. In addition, the algorithm of the Otsu method performs the calculation of the threshold value automatically.

\section{Distance Between People}

Having separated the people from the background of the image to be analyzed, what would be missing would be to locate the centroid of each of the people, and then calculate the distance. With this, the distance in which they are located would already be known.

To find the distance correctly, the camera must have 2 focus angles. This would help the system to have a more accurate measurement of the physical distance, as shown in Figure 4 (a), where the camera has a top view of the people, in Figure 4 (b), the camera has a profile view of the people. This would avoid inconveniences when people cross each other.

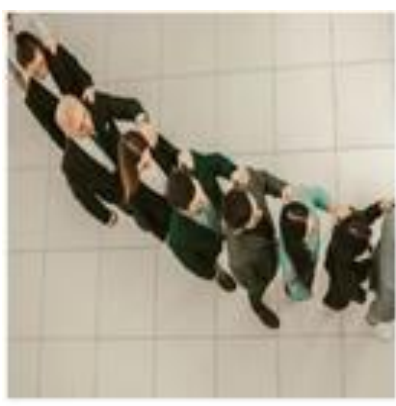

(a)

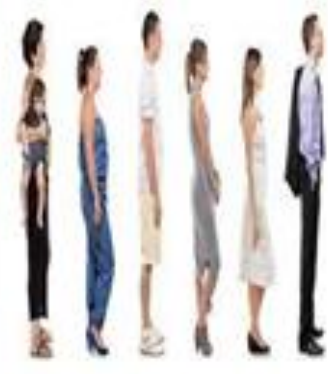

(b)
Fig. 4. (a) Camera with top view. (b) Camera with profile view.

\section{A. Location of centroids}

The location of centroids consists of finding the point where the intersection of the medians of an object is. To get to know the location of the centroids, it is necessary to perform some mathematical calculations. Once found, the determined point will be indicated as the center of mass.

The location of this point depends on two main factors, the shape of the structure and the material with which it is built, through its mass density. In the case in which the structure is made of a single material (constant density), the center of mass will depend only on the shape of the structure, in this case it is called centroid [19].

\section{B. Distance between centroids}

Having knowledge of the point of each centroid, we proceed to use the Euclidean distance formula between two points, with this we would already have the value of the distance in which the points of each centroid are located.

This distance between two points would be the existing separation between two pixels since we are analyzing an image in the two-dimensional plane. As shown in figure 5. 


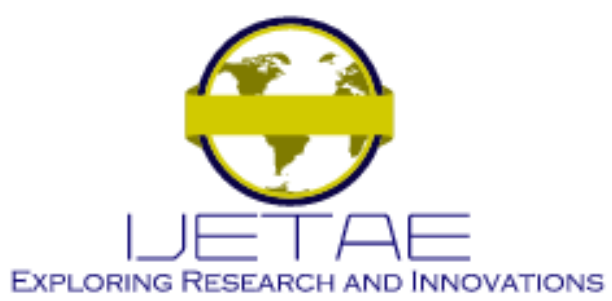

International Journal of Emerging Technology and Advanced Engineering

Website: www.ijetae.com (E-ISSN 2250-2459, Scopus Indexed, ISO 9001:2008 Certified Journal, Volume 11, Issue 12, December 2021)

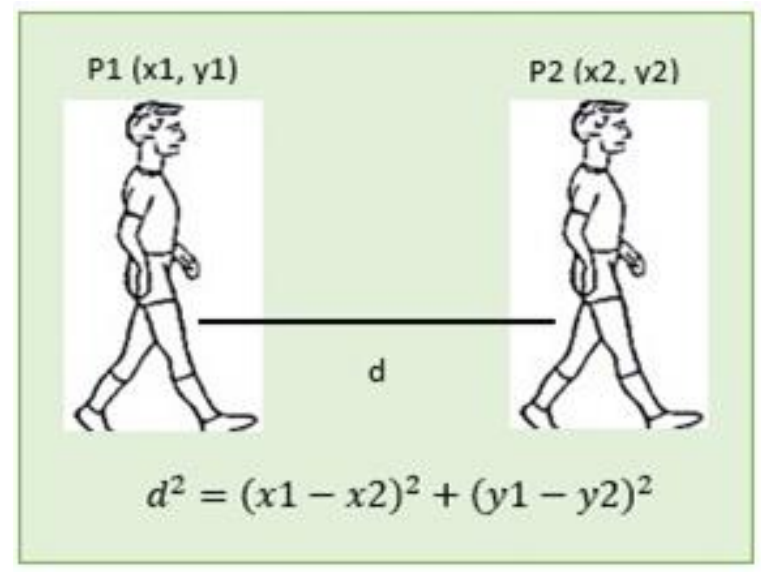

Fig. 5. Distance between two points

In this image, you can see the equation used to calculate the distance between people who are in the same place. It is a representation of what will be done in the Python program.

\section{RESULTS}

In this paper, the design of a distance detection system for patients within a health center was conducted. Therefore, it would be fulfilling the purpose of knowing the distance in which people are located within a health center, even with the system, the distance of several people could be known simultaneously through surveillance cameras.

Table I shows the characteristics of the system design:

TABLE 1:

ChaReCTERISTICS OF THE DiSTANCE DETECTION SYSTEM

\begin{tabular}{|c|c|}
\hline \multicolumn{2}{|c|}{ Distance detection } \\
\hline Camera height & $3 \mathrm{~m}$ \\
\hline Focal distance & $\begin{array}{c}\text { Normal: } 0-35 \mathrm{~mm} \\
\text { Maximum } 55-105 \mathrm{~mm}\end{array}$ \\
\hline $\begin{array}{c}\text { Part where the image } \\
\text { is captured }\end{array}$ & Full body \\
\hline $\begin{array}{c}\text { System calculation } \\
\text { time }\end{array}$ & 1 minute \\
\hline
\end{tabular}

The focal length will depend on the type of camera used in the place, but it is recommended that it does not exceed the specified range. The system will analyze the image and take the complete shape of the person so that it can determine the distance.

Figure 6 shows the distance detection system that will be extremely useful to reduce the number of COVID-19 infections.

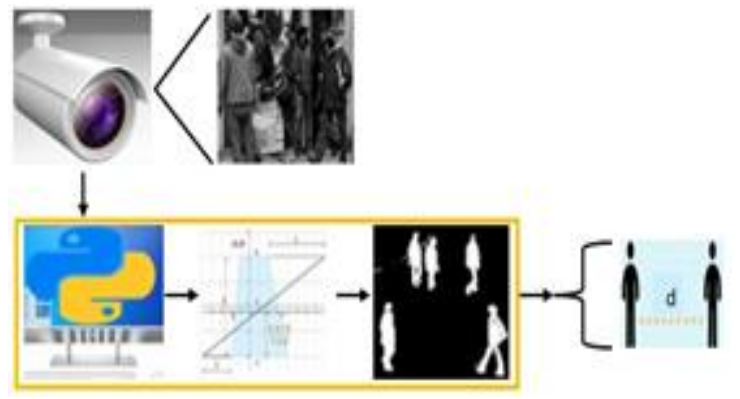

Fig. 6. Distance detection system

The camera focuses on the people who are inside the place, it should be noted that the camera must have a line of sight, that is, that there is no obstacle that makes it difficult to capture the images of the place or people completely. Once the image is obtained, it is processed in the Python program, with the various techniques to be able to detect the people in the analyzed image. After the image has been processed, the value of the distance between two different people will be displayed.

On the other hand, to implement the system, it is necessary to have the electronic equipment specified in the operating diagram. Also have the Python program since it is a valuable tool to be able to perform image processing. Also, all the specified characteristics such as the focal length and the height of the camera must be considered. With these specified values, the system will function properly.

The system can be used, not only in health centers, but it can also be used in places where there is an agglomeration of people, as can be seen in figure 7 (a), where people queue to enter a shopping center in figure 7 (b), the processed image is already observed, with the value of the distance in which each person is. Therefore, with this system, social distancing is enforced to prevent the spread of the virus that is currently around us. 


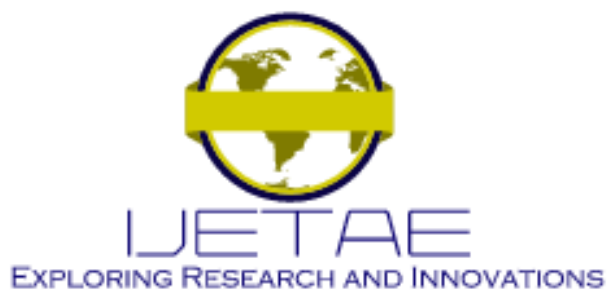

International Journal of Emerging Technology and Advanced Engineering Website: www.ijetae.com (E-ISSN 2250-2459, Scopus Indexed, ISO 9001:2008 Certified Journal, Volume 11, Issue 12, December 2021)

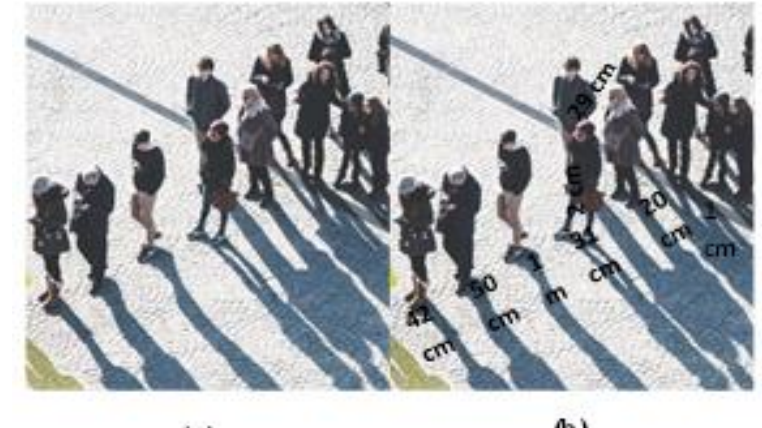

(a)

(b)

Fig. 7. (a) Image of the surveillance camera. (b) Image processed to detect distance

\section{DISCUSSION}

There are many research articles about COVID-19, which seek to provide information to combat it since it is a silent disease that can affect anyone.

The present research work aims to help prevent the spread of COVID-19, therefore, it has some differences from other research works, for example, the work carried out by [13], where the authors propose to develop an Accurate real-time pedestrian detection system with unmanned aerial vehicles for monitoring social distancing in the COVID-19 pandemic. Of which, they obtained a result of $92.22 \%$ efficiency, but this system, when working with a database, can introduce false information.

We also have the work developed by [14], where the authors propose to develop COVID-19 social distancing in an effective, efficient and safe way, focusing a lot on the importance of the use of the drone and what can be applied. Of which, they obtained a result of $90.1 \%$ efficiency, but this system does not indicate the temperature of the people, it only focuses on social distancing, being not so efficient.

We also have the work developed by [15], where the authors propose to develop a web system to monitor body temperature with an automatic antibacterial gel dispenser to prevent COVID-19 infections, that is, they automated the application of gel to the hands and the taking temperature of people, of which they obtained a result of $98.1 \%$, but this system does not focus on the social distancing that people should have.

We also have the work developed by [16], where the author proposes to develop the implementation of a social distancing recognition system as a preventive measure for COVID-19 using Deep Learning. While it is true, they had a result of $80 \%$ efficiency, but this system cannot detect when a person has an elevated temperature.

\section{CONCLUSION AND RECOMMENDATION}

It is concluded that the function of the system is the most appropriate, measuring the distance between people more precisely, unlike other systems. Therefore, this system would help prevent COVID-19 from spreading further between people. In addition, specify that only the images that are generated through the surveillance cameras of the place are required.

It is concluded that the use of the system is safe because it does not require any physical contact, only of a person who is observing through the cameras so that he can see if the distance between the people within the place is fulfilled and give the corresponding notice.

It is concluded that the system can show the distance measurement instantly, thus helping to maintain order within the health center and avoid crowding of people when there is no corresponding order.

It is concluded that the system can be implemented in any place where you want to have knowledge of the distance between people, especially in closed places. Therefore, this system is significant because it can be developed in the best way and has no limitations in its use.

It is concluded that COVID-19 has not yet disappeared and is still around us, this is worrying because there is an increase in the number of infections among people, this is because people think that the virus has disappeared and are completely careless and do not comply with biosecurity measures. Currently, we continue to see how in various places the number of infections continues to increase daily. Therefore, it is necessary to be strict with people to comply with biosecurity measures and mainly with the physical distancing in order to combat the virus.

It is concluded that people who are inside a health center do not comply with the physical distance, this is of concern because being a health center can generate a focus of contagion due to the fact that many people go there. Therefore, the personnel in charge should strictly enforce physical distancing within the health center, so that people are aware that it is important to maintain physical distancing, which many times they do not comply with, so they should be strict with those who do not comply.

As work in the future, the implementation of the system will be conducted, and the most appropriate electronic equipment will be used. Since this system will help prevent the spread of COVID-19 and with this, the number of infections between people would be reduced. 


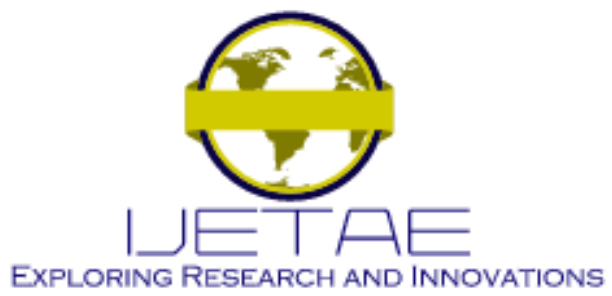

International Journal of Emerging Technology and Advanced Engineering Website: www.ijetae.com (E-ISSN 2250-2459, Scopus Indexed, ISO 9001:2008 Certified Journal, Volume 11, Issue 12, December 2021)

It is recommended that the characteristics be considered for proper system operation, such as the line of sight that the camera must have, otherwise the best results will not be obtained.

\section{REFERENCES}

[1] P. M. Buss and S. Tobar, "La COVID-19 y las oportunidades de cooperación internacional en salud," Cad. Saude Publica, vol. 36, no. 4, pp. 1-3, Apr. 2020, doi: 10.1590/0102-311X00066920.

[2] D. Amsalem, L. Dixon, and Y. Neria, "The Coronavirus Disease 2019 (COVID-19) Outbreak and Mental Health: Current Risks and Recommended Actions," JAMA Psychiatry, vol. 78, no. 1, pp. 9-10, Jan. 2021, doi: 10.1001/jamapsychiatry.2020.1730.

[3] M. Palacios Cruz, E. Santos, M. Velázquez Cervantes, and M. León Juárez, "COVID-19, a worldwide public health emergency," Rev. Clínica Española (English Ed., vol. 221, no. 1, pp. 55-61, Jan. 2021, doi: 10.1016/j.rceng.2020.03.001.

[4] E. Zevallos Santillan, J. Cruzado Burga, and R. Avalos Rivera, "COVID-19; Perú a los 100 días, breve observación de una pandemia que pone en serios aprietos a la salud pública mundial," Rev. Medica Hered., vol. 31, no. 4, pp. 287-289, Jan. 2020, doi: 10.20453/RMH.V31I4.3865.

[5] U. Cáceres Bernaola, C. Becerra Núñez, S. Mendívil Tuchía de Tai, and J. Ravelo Hernández, "Primer fallecido por COVID-19 en el Perú," An. la Fac. Med., vol. 81, no. 2, pp. 201-204, Jul. 2020, doi: 10.15381/ANALES.V81I2.17858.

[6] C. Maguiña Vargas, "Reflexiones sobre el COVID-19, el Colegio Médico del Perú y la Salud Pública," Acta Médica Peru., vol. 37, no. 1, pp. 8-10, Mar. 2020, doi: 10.35663/amp.2020.371.929.

[7] J. R. Huaman Fernández, "Impacto económico y social de la COVID-19 en el Perú," Rev. Cienc. e Investig. en Def. , vol. 2, no. 1, pp. 31-42, Feb. 2021.

[8] D. Valencia Huaman, "La educación primaria en tiempo de la pandemia del Covid-19. el caso de Chile y Perú durante el 2020," Universidad San Ignacio de Loyola, Lima - Perú, 2020.

[9] V. Meza Juárez, "APAVIT y turismo seguro post pandemia del Covid-19," Universidad de Lima, Lima - Perú, 2020.

[10] I. Condori Lizárraga, "Revisión de las evidencias propuestas por la normatividad establecida en los protocolos de bioseguridad para la prevención, vigilancia y control del covid-19 para empresas del rubro alimentación y alojamiento en el Perú," Universidad Peruana Cayetano Heredia, Lima - Perú, 2021.
[11] C. Cruz De La Cruz and J. Haqquehua Merejildo, "Habitus del distanciamiento social frente al COVID-19 en adultos jóvenes que utilizan el transporte público," universidad nacional de trujillo, Trujillo - Perú, 2021.

[12] N. Jones, Z. Qureshi, R. Temple, J. Larwood, T. Greenhalgh, and L. Bourouiba, "Dos metros o uno: ¿cuál es la evidencia del distanciamiento físico en COVID-19?,” Aug. 25, 2020. .

[13] Z. Shao, G. Cheng, J. Ma, Z. Wang, J. Wang, and D. Li, "Real-time and Accurate UAV Pedestrian Detection for Social Distancing Monitoring in COVID-19 Pandemic," IEEE Trans. Multimed., 2021, doi: 10.1109/TMM.2021.3075566.

[14] P. Somaldo, F. Ferdiansyah, G. Jati, and W. Jatmiko, "Developing Smart COVID-19 Social Distancing Surveillance Drone using YOLO Implemented in Robot Operating System simulation environment,” 2020 IEEE 8th R10 Humanit. Technol. Conf., pp. 16, Dec. 2020, doi: 10.1109/R10-HTC49770.2020.9357040.

[15] K. Chicaiza Moncayo and G. Cordero Cerezo, "Desarrollo sistema web para monitoreo de temperatura corporal con dispensador automático gel antibacterial para prevenir contagios COVID-19 locales comerciales en Guayaquil mediante el uso de Arduino," Universidad de Guayaquil, Guayaquil - Ecuador, 2020.

[16] W. S. Córdova Eras, "Implementación de un sistema de reconocimiento de distanciamiento social como medida preventiva para covid 19 usando deep learning," Machala: Universidad Tëcnica de Machala, Machala - Ecuador, 2020.

[17] S. Castro Casadiego, C. Niño Rondón, and B. Medina Delgado, "Caracterización para la ubicación en la captura de video aplicado a técnicas de visión artificial en la detección de personas," Rev. Colomb. Tecnol. Av., vol. 2, no. 36, pp. 83-88, Jul. 2020, doi: 10.24054/16927257.V36.N36.2020.3720.

[18] N. Rosero Acosta, J. Cabrera Rosero, M. Anrango Oyagata, M. Yandún Velasteguí, and S. Lascano Rivera, "Detección de enfermedades en cultivos de Papa usando procesamiento de imágenes," Cumbres, vol. 6, no. 1, pp. 43-52, May 2020, doi: 10.48190/CUMBRES.V6N1A4.

[19] S. Carrasquel Oropeza, D. Coronado, R. Monascal, and R. Rodríguez, "Ordenamiento de números difusos usando centroides: Aspectos prácticos," Publicaciones en Ciencias y Tecnol. ISSN 1856-8890, ISSN-e 2477-9660, Vol. 12, N ${ }^{\circ} .2$ (Julio-Diciembre), 2018, págs. 105-116, vol. 12, no. 2, pp. 105-116, 2018. 